\title{
An Additional risk of Lung Cancer from Recurrent Exposure to Ethyl Carbamate (EC) in BALB/C Mice
}

\author{
Mohamed A Hamzawy ${ }^{1 *}$, Amira M Abo-youssef ${ }^{2}$, Heba F Salem ${ }^{3}$ and Sameh Mohamed A ${ }^{2}$ \\ ${ }^{1}$ Faculty of Pharmacy, Pharmacology and Toxicology Department, Beni-Suef University, Beni-Suef, Egypt \\ ${ }^{2}$ Pharmacology and Toxicology Department, College of Pharmacy, Misr University for Science and Technology, 6th October City, Egypt
}

${ }^{3}$ Pharmaceutics Department, Faculty of Pharmacy, Beni-Suef University, Beni-Suef, Egypt

\begin{abstract}
Ethyl carbamate (EC); urethane is a chemical carcinogen (IARC group 2A). It has been commonly found in the fermented food and beverages. EC induced cancerous lesion in different sites due to the formation of active metabolite; vinyl carbamate (VC). The current study aims to investigate the potential risk of cancerous lesions in small and repeated exposure of ethyl carbamate in BALB/C mice. Three groups of BALBL/C mice were treated for 120 days included untreated control; group treated with a single dose of urethane $(1.5 \mathrm{~g} / \mathrm{kg} \mathrm{B.w} / \mathrm{i} . \mathrm{p})$ at a day one; group treated with repeated doses, the first at a day one and a second at day sixty $(1.5 \mathrm{~g} / \mathrm{kg} \mathrm{B}$.w/i.p). Ethyl carbamate (EC) exposure showed sever changes of serum biochemical markers, apoptosis markers, inflammatory cytokines as well as lipid peroxide formation in lung homogenate, these changes were pronounced in repeated exposure to ethyl carbamate. In addition, histological examinations revealed that epithelial changes in pulmonary tissues were advanced in animals treated with repeated doses of ethyl carbamate. These findings indicate that repeated exposure to ethyl carbamate of fermented foods and beverages is an additional risk for lung cancer due to permanent mitochondrial dysfunction and increase the cellular mitotic activity.
\end{abstract}

Keywords: Ethyl carbamate; Urethane; Lung cancer; Oxidative stress; Mitochondrial dysfunction

\section{Introduction}

Ethyl carbamate (EC); urethane is the ester of carbamic acid. It has been found mainly as a by-product of fermented foods and beverages. EC is widely distributed in fermented foods and beverages, such as spirit, wine, beer, bread, soy sauce, and yoghurt, due to unintentional fermentation during production or storage process of fermented foods or beverages [1]. EC has been formed from substances like urea, hydrogen cyanide, citrulline, and $\mathrm{N}$-carbamyl compounds during foods and beverage fermentations [2]. Earlier studies reported that unrecorded wine is rich with EC due to reaction between ethyl alcohol and hydrogen cyanide or urea wine [3]. The Joint Food and Agriculture Organization of the United Nations (FAO)/World Health Organization (WHO) Expert Committee on Food Additives (JECFA) reported that EC increase the probable health risk of carcinogenicity of certain types of alcoholic beverages for regular drinkers, especially in unrecorded alcohol $[3,4]$. EC exhibits carcinogenic activity on different sites such as the liver, ovary, and skin in a dose dependent manner due to its potential genotoxic activity [5]. Accordingly, IARC in 2007 upgraded its classification of EC to group 2A (probably carcinogenic to humans) [6]. There is mounting evidence that suggests carcinogenic effects of EC due to formation of DNA-reactive carcinogens, in rodent cells, is also likely to occur in humans due to significant similarities with rodents (IARC). In addition, it is still limited evidence to associate between ethyl carbamate exposures with the cancer incidence in order to attain causeeffect relationship [7]. Considering the importance of determining the risk of exposure to ethyl carbamate in fermented beverages or foods, the current study aims to investigate the potential carcinogenic effect of recurrent exposure of $\mathrm{EC}$ in $\mathrm{BALB} / \mathrm{C}$ mice.

\section{Material and Methods}

\section{Materials}

Ethyl carbamate (urethane) was purchased from Sigma chemical company, St Louis, MO, USA. Carcinoembryonic antigen (CEA), insulin growth factor (IGF-1) and Cytokeratin 19 fragments (CYFRA21-1) kits were purchased from Alpco Diagnostics (Salem, USA). Interleukin- $1 \beta$ (IL-1 $\beta$ ) kits were obtained from Assaypro (MO, USA). Tumor Necrosis Factor- $\alpha$ (TNF- $\alpha$ ) was purchased from the RandD System company (MN, USA). However, alpha-fetoprotein (AFP) was obtained from KAMIYA biomedical company (WA, USA). Lactate dehydrogenase (LDH) kit was purchased from USCN life science (USA). On the other hand, determination of reduced glutathione activities (GSH) and malondialdehde (MDA) levels were performed chemically. All other chemicals were of the highest analytical grade available.

\section{Animals and maintenance}

Male BALB/c mice (5 weeks, 22-30 g) each were purchased from Animal House Colony, Pharmacology and Chemistry Research Centre, $6^{\text {th }}$ October, Egypt. Animals were maintained on a standard lab diet (protein: 160.4; fat: 36.3; fiber: $41 \mathrm{~g} / \mathrm{kg}$ of metabolisable energy $=12.08$ $\mathrm{MJ})$ and were housed in filter-top polycarbonate cages in a room free from any source of chemical contamination, artificially illuminated (12h dark / light cycle) and thermally controlled $\left(25 \pm 1^{\circ} \mathrm{C}\right)$ at the Animal House Lab., Pharmacology and Chemistry Research Centre. All animals received humane care in compliance with the guidelines of the Animal Care and Use Committee of the Pharmacology and Chemistry Research Centre. All the procedures described below were

*Corresponding author: Hamzawy MA, Misr University for Science and Technology, P.O.Box: 77, 6th of October City, Egypt Al-Motamayez District, Egypt, Tel: 201001842988; E-mail: hamzawymohamed@gmail.com

Received October 27, 2015; Accepted November 28, 2015; Published November 30,2015

Citation: Hamzawy MA, Abo-youssef AM, Salem HF, Sameh Mohamed A (2015) An Additional risk of Lung Cancer from Recurrent Exposure to Ethyl Carbamate (EC) in BALB/C Mice. J Cancer Sci Ther 7: 359-362. doi:10.4172/1948-5956.1000374

Copyright: (๑) 2015 Hamzawy MA, et al. This is an open-access article distributed under the terms of the Creative Commons Attribution License, which permits unrestricted use, distribution, and reproduction in any medium, provided the original author and source are credited. 
Citation: Hamzawy MA, Abo-youssef AM, Salem HF, Sameh Mohamed A (2015) An Additional risk of Lung Cancer from Recurrent Exposure to Ethyl Carbamate (EC) in BALB/C Mice. J Cancer Sci Ther 7: 359-362. doi:10.4172/1948-5956.1000374

carried out in accordance with guidelines of ethics committee of the faculty of pharmacy, Beni-Suef University, Beni-Suef, Egypt.

\section{Preparation of Ethyl carbamate solution}

Ethyl carbamate (EC) was freshly prepared prior injection by dissolving 1.5 gm ethyl carbamate in $0.9 \% \mathrm{NaCl}$ to obtain $(1.5 \mathrm{~g} / 10 \mathrm{ml})$ [8].

\section{Experimental design}

Animals within treatment groups were assigned into three groups (10 mice/group) for 120 days as follows; Group (1), untreated control; Group (2), Animals treated with single exposure of ethyl carbamate (1.5 g/Kg/i.p); Group (3), Animals treated with repeated exposure of ethyl carbamate $(1.5 \mathrm{~g} / \mathrm{kg} / \mathrm{i} . \mathrm{p})$ at the first day and at day 60 of the treatment period.

\section{Mice blood and lung collection}

At the end of the treatment period, animals were fasted for about 12 hours, but with free access to water ad libitum. Blood samples were collected from each animal from the tail vein under ketamine $(12.5 \mathrm{mg} /$ $\mathrm{kg})$ and xylazine $(1.5 \mathrm{mg} / \mathrm{kg})$ anesthesia [9]. Blood samples were left to clot and the sera were obtained using cooling centrifugation at 3,000 rpm for 15 minutes and refrigerated at $-20^{\circ} \mathrm{C}$ until analysis. The sera were used for the determination of TNF- $\alpha$, IL- $1 \beta$, LDH, AFP, CEA, CYFRA21-1, and IGF-1 according to instruction of analytical kits. After the collection of blood samples, the animals were killed by over dose anesthesia and samples of the lungs were weighed (each approximately $0.05-0.1 \mathrm{~g}$ ) and homogenized in phosphate buffer ( $\mathrm{pH} 7.4$ ) to give $20 \%$ $\mathrm{w} / \mathrm{v}$ homogenate. This homogenate was centrifuged at $1700 \mathrm{rpm}$ at $4^{\circ} \mathrm{C}$ for $10 \mathrm{~min}$ and the supernatant was stored at $-70^{\circ} \mathrm{C}$ until analysis. The supernatant of lung homogenate was used for assessment of GSH activities and MDA (malondialdehyde) levels, according to method of Beutler et al., [10] and Mihara and Uchiyama, [11], respectively. Another sample of each lung was removed and fixed in $10 \%$ formalin and embedded in paraffin wax for the histological examination [12].

\section{Statistical analysis}

All data were statistically analyzed by analysis of variance (ANOVA) using the General Linear Model Procedure of the Statistical Analysis System [13]. The significance of the differences among treatment groups was determined by Waller-Duncan k-ratio [14]. All statements of significance were based on probability of $\mathrm{P}<0.05$.

\section{Results}

Effect of ethyl carbamate exposure on serum level of LDH, and tumor markers

The effect of exposure of ethyl carbamate (EC) demonstrated in Table 1 revealed single exposure of EC showed significant increase of LDH, CEA and AFP, while the increment of LDA, CEA and AFP was pronounced in animals treated with repeated doses of EC in comparison to single exposure or control itself.

\begin{tabular}{|c|c|c|c|}
\hline Treatments & LDH (U/L) & AFP $(\mathbf{p g} / \mathbf{m l})$ & CEA $(\mathbf{n g} / \mathbf{m l})$ \\
\hline Control & $38.03 \pm 3.38$ & $4.7 \pm 0.44$ & $3.36 \pm 0.28$ \\
\hline Single dose & $126.33 \pm 6.96$ & $37.77 \pm 5.88$ & $34.07 \pm 5.83$ \\
\hline Repeated dose & $229.43 \pm 16.38$ & $85.4 \pm 5.48$ & $74.57 \pm 5.16$ \\
\hline
\end{tabular}

Within row, means superscript with different letters are significantly different $(\mathrm{P}<0.05)$.

Table 1: Effect of single or repeated dose of ethyl carbamate on serum LDH, AFP, CEA in BALB/C mice.

\section{Effect of single or recurrent exposure of EC on inflammatory cytokines}

The results of the current study revealed that EC induced severe changes of serum TNF- $\alpha$, and IL- $1 \beta$ in comparison to control group. Recurrent exposure to EC showed significant increase in serum level of TNF- $\alpha$ and IL- $1 \beta$ in comparison to animals treated with a single dose of urethane (Table 2).

\section{Effect of ethyl carbamate on serum level of CYFRA21-1 and IGF-1}

The results of the current work showed at Table 3 that animals treated with a single dose of EC exhibit significant increase of serum level of CYFRA21-1 and IGF-1, while repeated doses of EC induce serum levels of CYFRA21-1 and IGF-1 significantly in comparison to a single dose of EC.

\section{Effect of ethyl carbamate on lipid peroxidation and oxidative stress of lung homogenate}

Animal treated with a single exposure of ethyl carbamate demonstrated a significant increase of lipid peroxidation and significant reduction of GSH activities in lung homogenate. However, recurrent administration of ethyl carbamate increases the lipid peroxidation and oxidative stress that indicated by significant increment of MDA level and reduction of GSH in comparison to single exposure of EC (Table 4).

\section{Histological examinations}

The results of the current study confirmed with histological examinations that demonstrated photomicrograph of pulmonary tissues of the control group showed no incidence of tumor nodules or microscopic lesions accompanied with normal epithelization of the bronchi, bronchioles and alveoli (Figure 1A). Mice treated with a single dose of ethyl carbamate demonstrated marked bronchiolar hyperplasia and subepithelial edema of the epithelial lining of bronchioles. Minute

\begin{tabular}{|c|c|c|}
\hline Treatment & TNF- $\boldsymbol{\alpha}(\mathbf{P g} / \mathbf{m l})$ & IL-1 $\boldsymbol{\beta} \mathbf{( n g / m l )}$ \\
\hline Control & $34.77 \pm 3.03$ & $25.33 \pm 1.16$ \\
\hline Single dose & $105.57 \pm 7.79$ & $84.8 \pm 3.3$ \\
\hline Repeated dose & $223.67 \pm 16.31$ & $209.03 \pm 15.5$ \\
\hline
\end{tabular}

Within row, means superscript with different letters are significantly different $(\mathrm{P}<0.05)$.

Table 2: Effect of single or repeated dose of ethyl carbamate on serum TNF- $\alpha$ and $\mathrm{IL}-1 \beta$ levels in BALB/C mice.

\begin{tabular}{|c|c|c|}
\hline Treatment & GSH $(\mathbf{n m o l} / \mathbf{m g})$ & MDA $(\mathbf{n m o l} / \mathbf{m g})$ \\
\hline Control & $0.0418 \pm 0.0017$ & $182.657 \pm 10.14$ \\
\hline Single dose & $0.0361 \pm 0.001$ & $244.17 \pm 3.03$ \\
\hline Repeated dose & $0.0173 \pm 0.003$ & $272.99 \pm 2.56$ \\
\hline
\end{tabular}

Within row, means superscript with different letters are significantly different $(\mathrm{P}<0.05)$

Table 3: Effect of single or repeated dose of ethyl carbamate on lipid peroxidation and oxidative stress of lung homogenate.

\begin{tabular}{|l|c|c|}
\hline Treatment & CYFRA 21-1 (ng/ml) & IGF-1 (ng/ml) \\
\hline Control & $1.22 \pm 0.14$ & $26.3 \pm 1.03$ \\
\hline Single dose & $10.22 \pm 0.84$ & $66.13 \pm 7.89$ \\
\hline Repeated dose & $21.27 \pm 1.19$ & $210.77 \pm 15.97$ \\
\hline Within row, means superscript with different letters are significantly different \\
\hline
\end{tabular}
$(\mathrm{P}<0.05)$.

Table 4: Effect of single or repeated dose of ethyl carbamate on serum CYFRA 21-1 and IGF-1 of BALB/C mice. 
focci was characterized with neoplastic cells at the peribronchial tissues and others were scattered between the alveoli (Figure 1B). Animals treated with repeated doses of ethyl carbamate (urethane) showed pronounced lesion accompanied with focal aggregation of neoplastic epithelial cells around the bronchioles. However, repeated exposure showed a marked increase of atypism, pleomorphism and mitotic activity and tissue necrosis around bronchi in reference to a single dose of urethane (Figure 1C).

\section{Discussion}

Nowadays there is an increase of the interest to determine and investigate the potential risk of recurrent exposure ethyl carbamate (EC) that found in the fermented beverages and wine. Animals treated with EC showed significant increase of LDH that indicated by cellular proliferation and cancer promotion [15]. It has been well documented that LDH plays an important role in the development, invasion, and metastasis of cancerous lesion such as lung cancer via accumulation of F-FDG (Fluorodeoxyglucose) [16]. On the other hand, the data of the current work showed either animals treated with a single or repeated dose of ethyl carbamate exhibited significant increase of AFP; important diagnostic marker for hepatocellular carcinoma and germ cell. Although, the elevation of AFP in lung carcinoma is very rare, but it may be due to a metastatic effect of ethyl carbamate on hepatocytes and other sites [17]. Previous studies reported that AFP could be elevated with patient of primary lung cancer due to hepatic or testicular metastasis [18]. Carcinogenic effect of EC may be due to the formation of active metabolite; Vinyl carbamate (VC), which is potent mutagen and promote formation of electrophilic species that interact with DNA to form the 2-oxoethyl adducts as vinyl chloride [19]. Animals treated with urethane showed significant increase of CEA and the increment was pronounced in the group treated with repeated doses of EC (urethane) that indicated promotion of cellular proliferation of lung [20]. The results of the current study revealed that animals treated with urethane showed significant increase of IGF-1 and the increment was enhanced in the animals treated with recurrent exposure. Previous reports demonstrated that urethane induced pulmonary adenocarcinoma through up-regulation of NF-кB that stimulate IGF-1 and inhibit other tumour suppressor genes [21]. Data of the present work of animals treated with EC showed significant increase of CYFRA21-1 that indicated the carcinogenic effect of ethyl carbamate [22]. CYFRA21-1 is the epithelial cell markers and very sensitive and specific markers for non-small cell lung cancer [23]. Recurrent exposure to ethyl carbamate induced sever changes of lipid peroxidation and oxidative stress that indicated by significant increment of MDA (malondialdehyde) and reduction of GSH in lung homogenate in comparison to control group. This could be attributed to increase of intrinsic ROS generated in the mitochondria through formation of electrophilic species with permanent mitochondrial dysfunction of lung cells [24]. Mitochondrial dysfunction and oxidative stress of repeated exposure to EC may be over stimulation of IFN- $\gamma$-producing

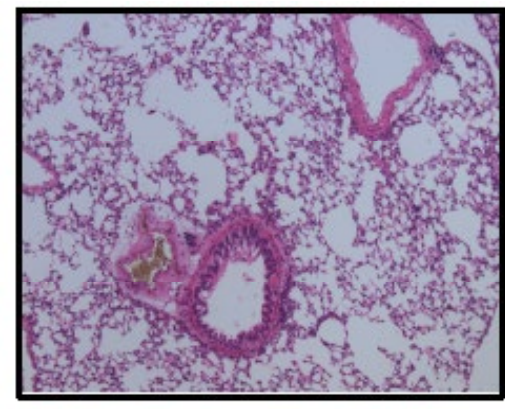

(A)

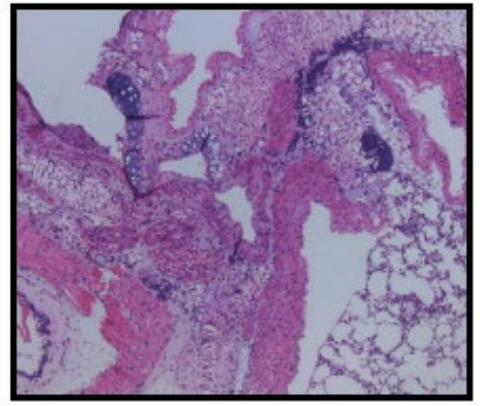

(B)

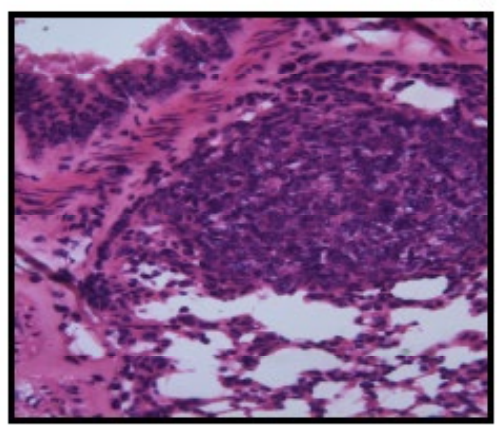

(C)

Figure 1: A photomicrograph of lung sections from (a) a control group showing normal epithelization of bronchi and bronchioles with normal alveoli and normal configuration of thymus (H \& E X 200), lung sections from (b) animal treated with single exposure of ethyl carbamate showing significant bronchiolar hyperplasia with sub-epithelial edema and rapid conversion to neoplastic cells accompanied with few mitotic activities (H \& E X 400), photomicrograph of lung sections of group treated with repeated exposure (c) showing foccal aggregation of neoplastic epithelial cells around the bronchioles and marked pleomorphic and advanced mitotic activities (H \& E X 200). Figure 1: A photomicrograph of lung sections from (a) a control group showing normal epithelization of bronchi and bronchioles with normal alveoli and normal configuration of thymus (H \& E X 200), lung sections from (b) animal treated with single exposure of ethyl carbamate showing significant bronchiolar hyperplasia with sub-epithelial edema and rapid conversion to neoplastic cells accompanied with few mitotic activities (H \& E X 400), photomicrograph of lung sections of group treated with repeated exposure (c) showing foccal aggregation of neoplastic epithelial cells around the bronchioles and marked pleomorphic and advanced mitotic activities (H \& E X 200). 
Citation: Hamzawy MA, Abo-youssef AM, Salem HF, Sameh Mohamed A (2015) An Additional risk of Lung Cancer from Recurrent Exposure to Ethyl Carbamate (EC) in BALB/C Mice. J Cancer Sci Ther 7: 359-362. doi:10.4172/1948-5956.1000374

cells, CD11 $\mathrm{b}^{+} \mathrm{Gr}-1^{+}$phenotype [25] as well as overexpression NF- $\mathrm{BB}$, COX-2, STAT3, IL-6 and cyclin D1 [26]. The results of the current study showed either single or repeated exposure to ethyl carbamate resulted in a significant increase of inflammatory cytokines; TNF- $\alpha$, IL- $1 \beta$ in comparison to control group. The results were in agreement with previous work that reported EC induce over expression of key molecules such as NF- $\kappa$ B, Stat3, pStat3; IL-1 $\beta$. They play a major role in pulmonary inflammation and adenocarcinoma [27]. It has been well documented that the molecular mechanism of ethyl carbamateinduced lung cancer is based on integration of TNF signals with NF-KB that accelerate tumour progression [28]. Histological studies confirmed the biochemical results of the current work. These results are in accordance with previous study by Nakahara et al. [29]. Microscopic examination showed that recurrent exposure of EC showed aggregation of epithelial cell due to significant increment of ROS production and ERK activation in macrophages that leads to enormous production of lung epithelial cells. The results of the current study demonstrate that ethyl carbamate is an additional risk of lung carcinoma and other types of cancer in fermented beverage and should encourage implicating a policy for prevention and counteracting unrecorded and contaminated beverages.

\section{Acknowledgements}

Extreme gratefulness and thanks are expressed to Dr. Mahmoud El-Begaway, Histopathology lab manager and Professor of Pathology, Faculty of Veterinary Medicine, Beni-Suef University for performing the Histopathological part in this manuscript.

\section{References}

1. Dennis MJ, Howarth N, Key PE, Pointer M, Massey RC (1989) Investigation of ethyl carbamate levels in some fermented foods and alcoholic beverages. Food Addit Contam 6: 383-389.

2. Júnior JCB, Mendonça RCS, Kluge JMAT, Pereira JAM, Soares NFF (2011) Ethyl-carbamate determination by gas chromatography-mass spectrometry at different stages of production of a traditional Brazilian spirit. Food Chemistry 129: $1383-1387$

3. Vavasour E, Renwick AG, Engeli B, Barlow S, Castle L, et al. (2006) Ethyl carbamate: Safety evaluation of certain contaminants in food (WHO Food Additives Series 55). Prepared by the sixty-fourth meeting of the Joint FAO/ WHO Expert Committee on Food Additives (JECFA) Geneva, Switzerland.

4. Lachenmeier DW, Lima MC, Nóbrega IC, Pereira JA, Kerr-Corrêa F, et al. (2010) Cancer risk assessment of ethyl carbamate in alcoholic beverages from Brazil with special consideration to the spirits cachaça and tiquira. BMC Cancer 10: 266.

5. Beland FA, Benson RW, Mellick PW, Kovatch RM, Roberts DW, et al. (2005) Effect of ethanol on the tumorigenicity of urethane (ethyl carbamate) in B6C3F mice. Food Chem Toxicol 43: 1-19.

6. IARC Working Group on the Evaluation of Carcinogenic Risks to Humans (2010) Alcohol consumption and ethyl carbamate. IARC Monogr Eval Carcinog Risks Hum 96: 3-1383.

7. Wogan GN, Hecht SS, Felton JS, Conney AH, Loeb LA (2004) Environmental and chemical carcinogenesis. Semin Cancer Biol 14: 473-486.

8. Gu Q, Hu C, Chen Q, Xia Y, Feng J, et al. (2009) Development of a rat model by ,4-benzopyrene intra-pulmonary injection and evaluation of the effect of green tea drinking on p53 and bcl-2 expression in lung carcinoma. Cancer Detect Prev 32: 444-451.

9. Bivas-Benita M, Zwier R, Junginger HE, Borchard G (2005) Non-invasive pulmonary aerosol delivery in mice by the endotracheal route. Eur J Pharm Biopharm 61: 214-218.

10. Beutler E, Kelly BM (1963) The effect of sodium nitrite on red cell GSH. Experientia 19: 96-97.

11. Mihara M, Uchiyama M (1978) Determination of malonaldehyde precursor in tissues by thiobarbituric acid test. Anal Biochem 86: 271-278.
12. Drury RAB, Wallington E (1967) Carleton's histological technique, New York Oxford University Press.

13. Stokes ME, Davis CS, Koch GG (2012) Categorical Data Analysis Using the SAS System. Cary NC, SAS Institute Inc.

14. Waller RA, Duncan DB (1969) A Bayes rule for the symmetric multiple comparisons problem. J Am Stat Assoc 64: 1484-1503.

15. Liu X, Yang Z, Chen Z, Chen R, Zhao D, et al. (2015) Effects of the suppression of lactate dehydrogenase $A$ on the growth and invasion of human gastric cancer cells. Oncol Rep 33: 157-162.

16. Zhou X, Chen R, Xie W, Ni Y, Liu J, et al. (2014) Relationship between 18F-FDG accumulation and lactate dehydrogenase $A$ expression in lung adenocarcinomas. J Nucl Med 55: 1766-1771.

17. Willder JM, Thomson AM, Grigor KM, Howard G, Stewart GD (2012) A unique case of an alpha-fetoprotein-producing lung cancer with testicular metastasis. Can Urol Assoc J 6: 364-366

18. Hernandez LG, Forkert PG (2007) In vivo mutagenicity of vinyl carbamate and ethyl carbamate in lung and small intestine of $F$ (Big Blue $\times A / J$ ) transgenic mice. Int J Cancer 120: 1426-1433.

19. Ding Y, Xuan W, Chen C, Chen Z, Yang Z, et al. (2014) Differences in carcinoembryonic antigen levels between colon and rectal cancer. Mol Clin Oncol 2: 618-622.

20. Cekanova M, Lee SH, Donnell RL, Sukhthankar M, Eling TE, et al. (2009) Nonsteroidal anti-inflammatory drug-activated gene- expression inhibits urethane-induced pulmonary tumorigenesis in transgenic mice. Cancer Prev Res (Phila) 2: 450-458.

21. Okamura K, Takayama K, Izumi M, Harada T, Furuyama K, et al. (2013) Diagnostic value of CEA and CYFRA 21- tumor markers in primary lung cancer. Lung Cancer 80: 45-49.

22. Wieskopf B, Demangeat C, Purohit A, Stenger R, Gries P, et al. (1995) Cyfra 21- as a biologic marker of non-small cell lung cancer. Evaluation of sensitivity, specificity, and prognostic role. Chest 108: 163-169.

23. Du G, Sun T, Zhang Y, Lin H, Li J, et al. (2013) The mitochondrial dysfunction plays an important role in urethane-induced lung carcinogenesis. Eur J Pharmacol 715: 395-404.

24. Kowaltowski AJ, de Souza-Pinto NC, Castilho RF, Vercesi AE (2009) Mitochondria and reactive oxygen species. Free Radic Biol Med 47: 333-343.

25. Pandey M, Gupta KP (2012) Involvement of STAT, NF-î̄B and associated downstream molecules before and after the onset of urethane induced lung tumors in mouse. Environ Toxicol Pharmacol 34: 502-511.

26. Narayan C, Kumar A (2012) Constitutive over expression of IL-1 1 , IL-6, NF$\kappa B$, and Stat3 is a potential cause of lung tumorgenesis in urethane (ethyl carbamate) induced Balb/c mice. J Carcinog 11: 9

27. Bernert H, Sekikawa K, Radcliffe RA, Iraqi F, You M, et al. (2003) Tnfa and II-10 deficiencies have contrasting effects on lung tumor susceptibility: genderdependent modulation of IL-10 haploinsufficiency. Mol Carcinog 38: 117-123.

28. Nakahara SB, Sanches DS, Caniceiro BD, Wysochi HL Jr, da Silva GB, et al (2013) Effects of selenium on Pteridium aquilinum and urethane-induced lung carcinogenesis. Immunopharmacol Immunotoxicol 35: 605-614.

29. Chun SH, Cha YN, Kim C (2013) Urethane increases reactive oxygen species and activates extracellular signal-regulated kinase in RAW 264.7 macrophages and A549 lung epithelial cells. Arch Pharm Res 36: 775-782. 